\title{
AC 2007-513: COST ESTIMATING CERTIFICATES OFFERED BY PROFESSIONAL SOCIETIES IN THE UNITED STATES AND ABROAD
}

\section{Donald Remer, Harvey Mudd College}

Donald S. Remer is the Oliver C. Field Professor of Engineering at Harvey Mudd College. He received his BSE at the Univ. of Michigan and his MS and PhD at Caltech. He is a registered professional Engineer in several states. He has presented short courses to thousands of engineers and managers in industry and government in the areas of Project and Engineering Management, Cost Estimation and Economic Evaluation of Projects, and Managing and Estimating Software Projects. He received the Centennial Award from ASEE.

\section{Karen Ahle, Raytheon}

Karen M. Ahle graduated from Harvey Mudd College in Claremont, California in May 2002 with a B.S. in engineering. She is working at Honeywell International, an aerospace and defense manufacturer in El Segundo, CA. Her interests are systems integration and hardware development.

\section{Kevin Alley, Southwest Research Institute}

Kevin J. Alley graduated from Harvey Mudd College in Claremont, California in May 2005 with a B.S. in engineering. He is working at Southwest Research Institute, a nonprofit research institute in San Antonio, Texas. His interests are in business management and law.

\section{John Silny, Raytheon}

John F. Silny graduated from both Harvey Mudd College and Claremont McKenna College in Claremont, California in May 2005 with a B.S. in engineering and a B.A. in economics respectively. He is working at Raytheon Corporation, a defense contractor in El Segundo, California. His interests are in business and project management.

\section{Karen Hsin, Accenture}

Karen Hsin graduated from Harvey Mudd College in Claremont, California in May 2006 with a B.S. in engineering. Upon graduation, she joined Accenture, a global management consulting, technology services, and outsourcing company in El Segundo, California. Her interests are in business and project management.

\section{Elijah Kwitman, Harvey Mudd College}

Elijah Kwitman graduated from Harvey Mudd College in Claremont, California in May 2007 with a B.S. in engineering. After graduation he plans to travel and pursue career opportunities in the field of engineering design and systems.

\section{Allison Hutchings, Harvey Mudd College}

Allison Hutchings graduated from Harvey Mudd College in Claremont, California in May 2007 with a B.S. in engineering. She plans to attend graduate school. Her interests are in structures and dynamics of aerospace systems. 


\title{
Cost Estimating Certificates Offered by Professional Societies in the United States and Abroad
}

\begin{abstract}
Many projects in industry and government go over budget and schedule. In most engineering economics courses, the emphasis is on how to compare alternatives and learn about time value of money and interest and inflation rates. The students are usually given the costs and asked to compare the alternatives. However, this is the easy part of the analysis. The hard part of real project evaluations is developing the cost and investment numbers to do the engineering economics analysis. In most engineering economic textbooks, there is at most one chapter on cost estimation. More and more companies and government organizations are concerned that their engineers don't know how to do accurate cost and schedule estimates. Cost estimation is a critical element to doing engineering economic evaluations. For example, one of the authors has presented short courses on cost estimation and economic evaluation to over 10,000 professionals, mostly engineers and engineering managers who are in industry and government. Most of these engineers have taken engineering economics courses while in college, and they have a good grasp of the fundamentals of engineering economics. However, most practicing engineers lack the fundamentals to do accurate cost and schedule estimates. To keep projects from going over budget and schedule, more and more organizations are requiring their engineers and engineering managers to obtain certifications in cost estimation from professional societies. The purpose of this paper is to discuss the current certifications offered so practicing engineers and engineering educators will know what is available and what is required to earn these certifications. The four major cost estimating certifications offered by professional societies in the United States are discussed. Eligibility and certification requirements along with examination information are presented. In addition, because many engineers are working on international projects, cost estimation certifications offered by professional societies in other countries are also summarized.
\end{abstract}

\section{Introduction}

Many engineering students take a course in engineering economics while they are in college; however, far fewer engineering students take a course in cost and schedule estimation. A large number of studies have shown that many projects in industry and government go way over budget or schedule. ${ }^{1-4}$ There are a lot of reasons for this, but one of the major reasons is that the engineers did an insufficient job on the estimate. One of the key reasons is that few engineering students get sufficient cost estimation training while they are in college. As a result, many industrial and governmental organizations are giving their practicing engineers and engineering managers short courses (one to five days) in cost and schedule estimation. There has been a strong push by companies and government organizations to enhance the cost estimation knowledge and in some cases organizations are requiring their engineers and engineering managers to obtain professional society certifications in cost and schedule estimation. 
There has been an increasing trend in professional and engineering circles to place greater emphasis on official credentials. These credentials commonly come in the form of certificates - documented recognition by a professional body that an engineer or other professional has the qualifications and technical knowledge to be a practitioner in that field. These certificates are somewhat analogous to merit badges in scouting - the certification is evidence that the holder has a certain minimum level of competence in the subject area. A recent publication $^{5}$ has discussed Project and Engineering Certificates offered by professional organizations in the United States and abroad. For example, there are over 180,000 engineers and other related professionals that hold the Project Management Certificate (PMP) offered by the Project Management Institute (PMI). In this paper, we will review the cost estimating certificates offered by professional societies for engineers and other professionals. This will help you decide what cost estimating certificates are applicable to you and the requirements to obtain a certification. Also, engineering educators will gain insight into the expanding area of estimating certifications offered by professional societies so they will be able to share this information with their students.

\section{COST ESTIMATING CERTIFICATIONS OFFERED IN THE U.S.}

\section{(1) Certified Professional Estimator (CPE)}

The Certified Professional Estimator (CPE) certificate is offered by the American Society of Professional Estimators (ASPE). The CPE certificate is targeted specifically at construction estimators, and requires a rigorous course of study. Construction estimates for the state of California must be prepared by, or under the direct supervision of, a Certified Professional Estimator. To be eligible to take the CPE certification test, the applicant must have at least five years experience in one discipline of professional estimating (mechanical, electrical, landscaping, etc.) The certification process consists of an educational workshop, writing a 2500 word acceptable technical paper on estimating, and completing two examinations. The educational workshop can be taken either at the ASPE Chapters during November and early December, or online. The first exam, a General Knowledge Exam, is designed to test project management and business knowledge. It is a four-hour exam with over 500 multiple choice and true/false questions on construction topics. A passing grade is $70 \%$. The second exam is a Discipline Specific Test, which tests a specific area of expertise. The ASPE is currently offering exams in: General Estimating, Earthwork, Concrete, Roofing, Drywall Systems, Painting, Plumbing, HVAC Piping, HVAC Sheet Metal, and Electrical. These are eight-hour exams and consist of true/false, multiple choice, and estimating problems. The exams are given at various dates given by the certification schedule online. ${ }^{6}$

\section{(2) Certified Cost Estimator/Analyst (CCE/A)}

The Certified Cost Estimator/Analyst (CCE/A) certificate is offered by the Society of Cost Estimating and Analysis (SCEA). The Certified Cost Estimator/Analyst certificate is much more general than the Certified Professional Estimator certificate. The body of knowledge required includes estimating in all fields of engineering, not just construction. To be eligible to take the CCE/A exam, the applicant must fit in one of three categories: having (1) a college 
degree (in cost estimating/analysis or with more than 10 courses in cost estimating and analysis) and two years experience in cost estimating/analysis in a position specifically identified as requiring such; (2) an associate's degree and five years experience as described above; or (3) seven years of experience as described above with submission of a biographical sketch demonstrating education, experience and relevant performance. The exam focuses on various methods of analyzing the cost of a project such as cost-benefit analysis and present worth analysis, as well as estimating models such as parametric estimating and comparison estimating. The exam is four hours long and consists of two parts. The first part is 80 to 100 multiple choice and true/false questions focusing mostly on terminology and concepts. The second part consists of 50 multiple choice questions focusing on calculations and problem solving. A passing score is $70 \%$ or more correct. The exam is given April, June, and November. ${ }^{7}$

\section{(3) Certified Parametric Practitioner (CPP)}

The Certified Parametric Practitioner certification is a new certificate offered by the International Society of Parametric Analysts (ISPA). This certificate provides professional recognition of a practitioner's education, job experience, knowledge, and skills. The first certification test was offered at the May 2002 ISPA Annual Conference in San Diego. To be eligible to take the written examination, the applicant must either have a college degree in a field of study directly related to parametric analysis (or at least ten courses related to estimating) and two years experience performing parametric analysis; an associate college degree and five years of experience in parametric analysis; or seven years of experience in parametric analysis with the submission of a brief biographical sketch demonstrating the applicant's ability or knowledge to pass the examination. The three-hour exam consists of 100 multiple-choice, fill in the blanks, and true/false questions. A passing grade is $75 \%$. The exam is given once annually at the ISPA Conference. ${ }^{8-9}$

\section{(4) Certified Cost Engineer/Consultant (CCE/CCC)}

The Certified Cost Engineer/Consultant certification is offered by the Association for the Advancement of Cost Engineering, International (AACEI). The AACEI was formerly known as the American Association of Cost Engineering (AACE). There are $909 \mathrm{CCE} / \mathrm{CCC}$ certified professionals, making this the largest cost estimating certification in our study. This certification is intended to provide official and public recognition of expertise in the most current skills and knowledge of the cost estimating profession. To be eligible to take the CCE/CCC certification test, the applicant must have at least eight full years in the cost engineering profession (up to four can be substituted for by an engineering degree or a PE license.) To become a Certified Cost Engineer or Consultant, the applicant must pass a 7-hour test, as well as writing a 2,500 word minimum technical paper. The exam consists of 100 multiple-choice and compound questions. A passing grade is $70 \%$. The exam is given any time, given the following four conditions are met (1) the AACE headquarters receive 40 days notice before the exam date, (2) the exam is offered to a group of at least five candidates, (3) the proctoring body must be a corporations, employer, of a local section of AACE, (4) all participants' applications must be received at the AACE headquarters at least 30 days before the exam date. 
The CCE certification is limited to those with a 4-year degree from an accredited engineering program. Additionally, in some states CCE certified people who are not licensed Professional Engineers (PEs) are not allowed to advertise themselves as having any engineering title (including that of Certified Cost Engineer). This is the purpose of the CCC certificate - to indicate that the holder has met all other requirements for being a Certified Cost Engineer, but either does not have a 4-year accredited engineering degree or is not permitted to use the CCE designation due to not being a licensed Professional Engineer. ${ }^{10}$

\section{TABLES OF CERTIFICATES}

In Table 1, we summarize the general information about each certification. The CCE/A certificate, offered by SCEA, has been available since 1990. There are 434 people with this certificate. ${ }^{11}$ AACEI and ASPE have been offering certifications since 1976, much longer than the other organizations. However, these certifications still have relatively small membership, with 909 CCE/CCC certificate holders ${ }^{12}$ and 647 CPE certificate holders. ${ }^{13}$ The newest certification, Certified Parametric Practitioner (CPP), is offered by ISPA, with the first certification test held in 2002, and currently has only 21 certificate holders. ${ }^{14}$

In Table 2, we summarize the requirements to take the test and the recertification requirements. To obtain a certificate, each organization has a combination of education and experience requirements. In general, as formal education increases, the experience requirement decreases. All of the certification programs require recertification. All of the organizations require recertification every three to five years. The American Society of Professional Estimators requires an annual number of points.

Table 3 contains information on the certification exams. The exams are typically in the four- to six-hour range. The exam cost varies from $\$ 75$ to $\$ 650$. Two of the organizations offer it biannually, and two offer the exam annually.

Table 4 includes information on how to contact the organizations offering each certification. All of the organizations have web sites and e-mail addresses.

Table 5 contains the contact information for the organizations located in Holland, United Kingdom, Italy, and Mexico. These organizations are linked through the International Cost Engineering Council. ${ }^{15}$

\section{Summary}

There has been a recent proliferation in professional organizations offering certificates in many areas of interest to engineers, managers and other professionals. This paper summarizes the cost estimating certificates of interest to practicing engineers, managers and other related professionals. There are over 2,000 engineers and related professionals holding these cost estimating certificates in the United States. There is also a significant interest in these certificates from engineers and other professionals in many countries. There are, for example, professional cost estimating societies in Holland, United Kingdom, Italy, and Mexico.

Because of this demand for practicing engineers, managers and other professionals to obtain cost estimating education, one of the authors has presented short courses to practicing professionals on cost estimation and related topics at Universities such as UCLA, Caltech, 
University of California at Riverside, and the University of Wisconsin at Madison. These short courses have also been presented at over 25 companies, national laboratories, and government agencies.

Many of these engineers and managers have strongly felt this topic should be introduced into the engineering undergraduate curriculum. To prepare our graduates at Harvey Mudd College for the challenges they will be facing in their careers in the complex global economy, we have introduced an elective course on cost estimation for our engineering majors. This course, which is a very popular elective, supplements our courses in engineering economics, engineering management, and project management. We suspect that there will be an increase in other colleges and universities incorporating cost estimation into their engineering curriculums. 
Table 1. General Information about the Certificates

\begin{tabular}{|c|c|c|c|c|c|c|c|}
\hline Certification & $\begin{array}{l}\text { Organization } \\
\text { Offering the } \\
\text { Certification }\end{array}$ & \begin{tabular}{|c|} 
Number of \\
Members in \\
the \\
Organization \\
\end{tabular} & $\begin{array}{c}\text { Number of } \\
\text { People with } \\
\text { the } \\
\text { Certificates }\end{array}$ & \begin{tabular}{|} 
Certificates \\
Issued in \\
2004
\end{tabular} & $\begin{array}{l}\text { Certificates } \\
\text { Issued in } \\
2005\end{array}$ & $\begin{array}{c}\text { First Year } \\
\text { Certificates } \\
\text { Offered }\end{array}$ & $\begin{array}{c}\text { Online } \\
\text { Registration }\end{array}$ \\
\hline $\begin{array}{l}\text { Certified } \\
\text { Professional } \\
\text { Estimator } \\
(\text { CPE }) \\
\end{array}$ & $\begin{array}{c}\text { American Society } \\
\text { of Professional } \\
\text { Estimators (ASPE) }\end{array}$ & 2500 & 647 & 48 & 37 & 1976 & No \\
\hline $\begin{array}{c}\text { Certified } \\
\text { Cost } \\
\text { Estimator / } \\
\text { Analyst } \\
\text { (CCE / A) }\end{array}$ & $\begin{array}{c}\text { Society of Cost } \\
\text { Estimating and } \\
\text { Analysis (SCEA) }\end{array}$ & 1266 & 434 & 21 & 42 & 1990 & No \\
\hline $\begin{array}{l}\text { Certified } \\
\text { Parametric } \\
\text { Practitioner } \\
\quad \text { (CPP) }\end{array}$ & $\begin{array}{c}\text { International } \\
\text { Society of } \\
\text { Parametric } \\
\text { Analysts (ISPA) }\end{array}$ & 240 & 21 & 4 & NA & 2002 & No \\
\hline $\begin{array}{c}\text { Certified } \\
\text { Cost } \\
\text { Engineer / } \\
\text { Consultant } \\
\text { (CCE / CCC) }\end{array}$ & \begin{tabular}{|} 
Association for the \\
Advancement of \\
Cost Engineering \\
International \\
(AACEI) -- \\
formerly American \\
Association of \\
Cost Engineers
\end{tabular} & 5032 & $566 / 343$ & 34 / 67 & $161 / 46$ & 1976 & $\begin{array}{c}\text { https://www.a } \\
\text { acei.org/certifi } \\
\text { cation }\end{array}$ \\
\hline
\end{tabular}


Table 2. Eligibility and Certification Requirements

\begin{tabular}{|c|c|c|c|}
\hline Certification & $\begin{array}{l}\text { Organization } \\
\text { Offering the } \\
\text { Certification } \\
\end{array}$ & Eligibility & $\begin{array}{l}\text { Recertification } \\
\text { Requirements }\end{array}$ \\
\hline $\begin{array}{c}\text { Certified } \\
\text { Professional } \\
\text { Estimator } \\
(\mathrm{CPE})\end{array}$ & $\begin{array}{c}\text { American Society of } \\
\text { Professional } \\
\text { Estimators (ASPE) }\end{array}$ & $\begin{array}{l}\text { At least } 5 \text { years experience in one discipline in professional } \\
\text { estimating (mechanical, electrical, landscaping, etc.) }\end{array}$ & $\begin{array}{c}30 \text { points every } 3 \text { years } \\
\text { (activity in the Society on } \\
\text { a local and national level, } \\
\text { committee membership } \\
\text { etc.) }\end{array}$ \\
\hline \begin{tabular}{|c|} 
Certified \\
Cost \\
Estimator / \\
Analyst \\
(CCE / A)
\end{tabular} & $\begin{array}{c}\text { Society of Cost } \\
\text { Estimating and } \\
\text { Analysis (SCEA) }\end{array}$ & $\begin{array}{l}\text { A. College degree (in cost estimating / analysis or with }>10 \\
\text { courses in cost estimating / analysis), } 2 \text { years experience in cost } \\
\text { estimating / analysis in a position specifically identified as } \\
\text { requiring such, OR } \\
\text { B. Associate's degree and } 5 \text { years experience as described above, } \\
\text { OR } \\
\text { C. } 7 \text { years experience as described above and a biographical } \\
\text { sketch demonstrating education, experience, and relevant } \\
\text { performance }\end{array}$ & $\begin{array}{l}\text { Re-passing exam OR } 30 \\
\text { points every } 5 \text { years (cost } \\
\text { related employment, } \\
\text { attendance at conferences, } \\
\text { leadership positions in } \\
\text { organizations, articles, } \\
\text { educational programs, } \\
\text { courses) }\end{array}$ \\
\hline $\begin{array}{c}\text { Certified } \\
\text { Parametric } \\
\text { Practitioner } \\
\text { (CPP) }\end{array}$ & $\begin{array}{c}\text { International Society } \\
\text { of Parametric } \\
\text { Analysts (ISPA) }\end{array}$ & $\begin{array}{l}\text { A. A college degree in parametric analysis / estimation or with a } \\
>10 \text { college level courses related to estimating. (statistics, } \\
\text { advanced statistics, parametrics, calculus, software cost } \\
\text { estimation, etc.), and } 2 \text { years experience performing parametric } \\
\text { analysis and estimating activities in a position specifically } \\
\text { identified as requiring such, OR } \\
\text { B. An associate college degree and } 5 \text { years experience in } \\
\text { performing parametric estimating and analysis activities in a } \\
\text { position as described above, OR } \\
\text { C. } 7 \text { years experience in parametric estimating or analysis } \\
\text { activities in a position as described above. Also, submission of a } \\
\text { biographical sketch describing education, experience, and most } \\
\text { recent relevant estimating or analysis performance is required. }\end{array}$ & every 5 years by retesting \\
\hline $\begin{array}{l}\text { Certified } \\
\text { Cost } \\
\text { Engineer / } \\
\text { Consultant } \\
\text { (CCE / } \\
\text { CCC) }\end{array}$ & \begin{tabular}{|c|} 
Association for the \\
Advancement of \\
Cost Engineering \\
International \\
(AACEI) -- formerly \\
American \\
Association of Cost \\
Engineers \\
\end{tabular} & $\begin{array}{c}8 \text { full years in the profession (up to } 4 \text { can be substituted for by an } \\
\text { engineering degree) }\end{array}$ & $\begin{array}{c}\text { every } 3 \text { years by testing or } \\
\text { by accumulating } 15 \\
\text { credits every } 3 \text { years } \\
\text { (employment as a cost } \\
\text { engineer, coursework, } \\
\text { teaching a course, } \\
\text { publishing a paper, } \\
\text { serving on a committee) }\end{array}$ \\
\hline
\end{tabular}


Table 3. Certification Exam Information

\begin{tabular}{|c|c|c|c|c|}
\hline Certification & $\begin{array}{l}\text { Organization } \\
\text { Offering the } \\
\text { Certification }\end{array}$ & Exam Type & Cost & Exam Frequency \\
\hline $\begin{array}{l}\text { Certified Professional } \\
\text { Estimator (CPE) }\end{array}$ & $\begin{array}{l}\text { American } \\
\text { Society of } \\
\text { Professional } \\
\text { Estimators } \\
\text { (ASPE) }\end{array}$ & $\begin{array}{l}\text { Workshop, technical } \\
\text { paper, written exam } \\
\text { (General Knowledge } \\
\text { Exam and Discipline } \\
\text { Specific Exam) }\end{array}$ & $\begin{array}{c}\$ 350 \text { for ASPE } \\
\text { members, } \$ 650 \text { for } \\
\text { nonmembers } \\
\text { (Base membership } \\
\$ 165)\end{array}$ & $\begin{array}{c}\text { Multiple deadlines, see website } \\
\text { (https://www.aspenational.com/cert- } \\
\text { schedule.pdf) }\end{array}$ \\
\hline $\begin{array}{c}\text { Certified Cost Estimator / } \\
\text { Analyst (CCE / A) }\end{array}$ & $\begin{array}{l}\text { Society of Cost } \\
\text { Estimating and } \\
\text { Analysis } \\
\text { (SCEA) }\end{array}$ & $\begin{array}{c}150 \text { questions } \\
\text { multiple choice (100 } \\
\text { on general } \\
\text { knowledge, } 50 \text { on } \\
\text { practical application) }\end{array}$ & $\begin{array}{c}\$ 125 \text { for SCEA } \\
\text { members, } \$ 250 \text { for } \\
\text { nonmembers }\end{array}$ & April, June, and November \\
\hline $\begin{array}{l}\text { Certified Parametric } \\
\text { Practitioner (CPP) }\end{array}$ & $\begin{array}{l}\text { International } \\
\text { Society of } \\
\text { Parametric } \\
\text { Analysts (ISPA) }\end{array}$ & $\begin{array}{c}3 \text { hour exam, } 100 \\
\text { questions, multiple } \\
\text { choice and fill in the } \\
\text { blank }\end{array}$ & $\begin{array}{c}\$ 75, \text { plus } \$ 75 \text { every } \\
\text { five years for } \\
\text { recertification by } \\
\text { exam } \\
\text { (membership } \$ 55 \\
\text { annually, } \$ 550 \text { for } \\
\text { life) }\end{array}$ & Annually at the ISPA Conference \\
\hline $\begin{array}{l}\text { Certified Cost Engineer / } \\
\text { Consultant (CCE / CCC) }\end{array}$ & $\begin{array}{c}\text { Association for } \\
\text { the } \\
\text { Advancement of } \\
\text { Cost } \\
\text { Engineering } \\
\text { International } \\
\text { (AACEI) -- } \\
\text { formerly } \\
\text { American } \\
\text { Association of } \\
\text { Cost Engineers }\end{array}$ & $\begin{array}{c}7 \text { hour exam (4 } \\
\text { sections with a total } \\
\text { of } 100 \text { multiple } \\
\text { choice and } \\
\text { compound questions) } \\
\text { and a } 2,500 \text { word } \\
\text { minimum technical } \\
\text { paper }\end{array}$ & $\begin{array}{c}\$ 350 \text { for an } \\
\text { AACEI member, } \\
\$ 475 \text { for a non- } \\
\text { member } \\
\text { (membership } \$ 130)\end{array}$ & $\begin{array}{c}\text { Anytime if: } \\
\text { - The AACE headquarters } \\
\text { receive 40-day notice before the } \\
\text { exam date } \\
\text { - The exam is offered to a group } \\
\text { of at least } 5 \text { candidates } \\
\text { - The proctoring body must be a } \\
\text { corporation, employer, or a local } \\
\text { section of AACE } \\
\text { - All participants' applications } \\
\text { must be received at AACE } \\
\text { Headquarters at least } 30 \text { days } \\
\text { before the exam date. }\end{array}$ \\
\hline
\end{tabular}


Table 4. Certification Contact Information

\begin{tabular}{|c|c|c|c|c|c|c|}
\hline Certification & $\begin{array}{l}\text { Organization } \\
\text { Offering the } \\
\text { Certification }\end{array}$ & URL & Phone \# & Fax \# & Address & Email Address \\
\hline $\begin{array}{c}\text { Certified } \\
\text { Professional } \\
\text { Estimator }(\mathrm{CPE})\end{array}$ & $\begin{array}{l}\text { American Society } \\
\text { of Professional } \\
\text { Estimators (ASPE) }\end{array}$ & www.aspenational.org & $\begin{array}{l}+615- \\
316- \\
9200\end{array}$ & $\begin{array}{l}+615- \\
316- \\
9800\end{array}$ & $\begin{array}{c}\text { ASPE } \\
2525 \text { Perimeter Place } \\
\text { Drive } \\
\text { Suite \#103 } \\
\text { Nashville, TN } 37214 \\
\text { USA } \\
\end{array}$ & info@aspenational.org \\
\hline $\begin{array}{l}\text { Certified Cost } \\
\text { Estimator / } \\
\text { Analyst (CCE / } \\
\text { A) }\end{array}$ & $\begin{array}{c}\text { Society of Cost } \\
\text { Estimating and } \\
\text { Analysis (SCEA) }\end{array}$ & www.sceaonline.net & $\begin{array}{l}+703- \\
751- \\
8069\end{array}$ & $\begin{array}{l}+703- \\
461- \\
7328\end{array}$ & $\begin{array}{c}\text { SCEA } \\
101 \text { South Whiting } \\
\text { Street } \\
\text { Suite 201 } \\
\text { Alexandria, VA } 22304 \\
\text { USA }\end{array}$ & scea@sceaonline.net \\
\hline $\begin{array}{c}\text { Certified } \\
\text { Parametric } \\
\text { Practitioner } \\
\text { (CPP) }\end{array}$ & $\begin{array}{c}\text { International } \\
\text { Society of } \\
\text { Parametric } \\
\text { Analysts (ISPA) }\end{array}$ & www.ispa-cost.org & $\begin{array}{l}+818- \\
957- \\
2340\end{array}$ & $\begin{array}{c}+818- \\
957- \\
2340 \\
\text { ext: } * 51\end{array}$ & $\begin{array}{c}\text { ISPA CPP Program } \\
\text { Fred Tucker } \\
\text { P.O. Box } 9699 \\
\text { Canoga Park, CA } 91309 \\
\text { USA }\end{array}$ & $\begin{array}{c}\text { ISPA- } \\
\text { office@earthlink.net }\end{array}$ \\
\hline $\begin{array}{c}\text { Certified Cost } \\
\text { Engineer / } \\
\text { Consultant (CCE } \\
\text { / CCC) }\end{array}$ & $\begin{array}{c}\text { Association for the } \\
\text { Advancement of } \\
\text { Cost Engineering } \\
\text { International } \\
\text { (AACEI) -- } \\
\text { formerly American } \\
\text { Association of } \\
\text { Cost Engineers }\end{array}$ & www.aacei.org & $\begin{array}{l}+800- \\
858- \\
2678\end{array}$ & $\begin{array}{l}+304- \\
296- \\
8444\end{array}$ & $\begin{array}{c}\text { AACE International } \\
209 \text { Prairie Ave., Suite } \\
100 \\
\text { Morgantown, WV } \\
26501 \\
\text { USA }\end{array}$ & mball@aacei.org \\
\hline
\end{tabular}


Table 5. Contact Information for Organizations with Headquarters Outside the United States

\begin{tabular}{|c|c|c|c|c|c|c|}
\hline Certification & $\begin{array}{l}\text { Organization } \\
\text { Offering the } \\
\text { Certification }\end{array}$ & URL & Phone \# & Fax \# & Address & Email Address \\
\hline $\begin{array}{c}\text { Certified Cost } \\
\text { Engineer }(\text { CCE })\end{array}$ & $\begin{array}{l}\text { Dutch Association } \\
\text { of Cost Engineers }\end{array}$ & www.napdace.nl & $\mid \begin{array}{c}3133247 \\
3460\end{array}$ & $\left|\begin{array}{c}3133246 \\
0470\end{array}\right|$ & $\begin{array}{c}\text { PO Box } 1058 \\
3860 \text { BB Nijkerk } \\
\text { THE } \\
\text { NETHERLANDS }\end{array}$ & napdace@mos-net.nl \\
\hline $\begin{array}{c}\text { Certified Cost } \\
\text { Engineer }(\mathbf{C C E})\end{array}$ & $\begin{array}{c}\text { Association of } \\
\text { Cost Engineers } \\
\text { (United Kingdom) }\end{array}$ & www.acoste.org.uk & $\begin{array}{c}+44 \\
(0) 1270 \\
764798\end{array}$ & $\begin{array}{c}+44 \\
(0) 1270 \\
766180\end{array}$ & $\begin{array}{c}\text { Lea House } \\
5 \text { Middlewich Road } \\
\text { Sandbach } \\
\text { Cheshire } \\
\text { CW11 1XL } \\
\text { United Kingdom }\end{array}$ & enquiries@acoste.org.uk \\
\hline $\begin{array}{c}\text { Practicante in } \\
\text { Ingegneria } \\
\text { Economica (PIE) }\end{array}$ & $\begin{array}{c}\text { Associazione } \\
\text { Italiana } \\
\text { d'Ingegneria } \\
\text { Economica (Italy) }\end{array}$ & www.aice-it.org & $\begin{array}{c}3902 \\
58304164\end{array}$ & $\begin{array}{c}3902 \\
58300106\end{array}$ & $\begin{array}{c}\text { Via Luigi Castiglioni } \\
120123 \text { Milano } \\
\text { ITALY }\end{array}$ & info@aice-it.org \\
\hline $\begin{array}{l}\text { Ingeniero en } \\
\text { Costos (ICC) }\end{array}$ & $\begin{array}{c}\text { Sociedad } \\
\text { Mexicana de } \\
\text { Ingenieria } \\
\text { Economica, } \\
\text { Financiera y de } \\
\text { Costos (Mexico) }\end{array}$ & www.smiefc.com.mx & $\begin{array}{c}525639 \\
5425\end{array}$ & $\left|\begin{array}{c}525639 \\
1145\end{array}\right|$ & \begin{tabular}{|l} 
Anaxagoras No. 17- \\
101, P.B. \\
Col Narvarte Deleg. \\
Benito Juarez \\
Codigo Postal 03020 \\
Mexico DF \\
MEXICO
\end{tabular} & smiefc@prodigy.net.mx \\
\hline
\end{tabular}




\section{References}

1. Steve McConnell, Software Estimation, Microsoft Press, 2006.

2. Rodney Stewart, Richard Wyskida, and James Johannes, Cost Estimator's Reference Manual, Second Edition, Wiley, 1995.

3. Frederick Brooks Jr., The Mythical Man-Month, Addison Wesley, 1995.

4. Edward Merrow, Kenneth Phillips, and Christopher W. Myers, Understanding Cost Growth and Performance Shortfalls in Pioneer Process Plants, Rand Corporation, 1981.

5. Donald S. Remer, Karen M. Ahle, Kevin J. Alley, John F. Silny, and Karen Hsin, "Project and Engineering Management Certificates Offered by Professional Organizations," Journal of Leadership and Management in Engineering, Volume 7, Issue 2, American Society of Civil Engineers, April 2007.

6. American Society of Professional Estimators. <www.aspenational.org> (April 4, 2006).

7. Society of Cost Estimating and Analysis. <www.sceaonline.net> (April 4, 2006).

8. Druley, Douglas. "FW: Questions about ISPA and CPP." E-mail to the author. April 18, 2005.

9. International Society of Parametric Analysts. < www.ispa-cost.org> (April 4, 2006).

10. Association for the Advancement of Cost Engineering, International. <www.aacei.org > (April 4, 2006).

11. Ceshire, Lenny. Personal Interview via Telephone. April 11, 2006.

12. Willard, Sandy. "Certification Statistics." E-mail to the author. April 4, 2006.

13. Parrish, Sue. "RE: Certification Statistics.” E-mail to the author. March 28, 2006.

14. Brown, Allison. "RE: Questions about ISPA and CPP.” E-mail to the author. March 29, 2005.

15. International Cost Engineering Council. <www.icoste.org> (April 4, 2006). 